\title{
Synthesis of Diethyl 1,2,3,4-Tetrathiepane-6,6-dicarboxylate: a New Heterocyclic System
}

\author{
Lene Teuber and Carsten Christophersen
}

\begin{abstract}
Marine Chemistry Section, The H. C. Ørsted Institute, University of Copenhagen, Universitetsparken 5, DK-2100 Copenhagen, Denmark
\end{abstract}

\begin{abstract}
Teuber, L. and Christophersen, C., 1988. Synthesis of Diethyl 1,2,3,4-Tetrathiepane-6,6-dicarboxylate: a New Heterocyclic System. - Acta Chem. Scand., Ser. B 42: $620-622$.

The title compound (4) has been identified in the reaction mixture of diethyl bis( $p$-tolylsulfonyloxymethyl)malonate and tetrasulfide ion, along with diethyl 1,2-dithiolane-4,4-dicarboxylate (2) and diethyl 1,2,3-trithiane-5,5-dicarboxylate (3). Reaction of 2 with elemental sulfur in $N, N$-dimethylformamide at elevated temperatures is a useful synthesis of 4 , giving only 3 as a side-product. Photoelectron spectroscopy indicates that the dihedral angles around the $S-S$ bonds of 4 are comparable to the normal value exhibited by straight-chain disulfides.
\end{abstract}

During a search for improved methods for the preparation of 4-substituted 1,2-dithiolanes, the reaction between diethyl bis ( $p$-tolylsulfonyloxymethyl)malonate (1) and the tetrasulfide ion was investigated ${ }^{1}$ with the intent of preparing a precursor of asparagusic acid (1,2-dithiolane-4-carboxylic acid). The method has previously been applied to the preparation of 1,2-dithiolanes ${ }^{2}$ and usually produces significant amounts of 1,2,3trithianes. ${ }^{1-5}$ Hence, the reaction mixture is desulfurized prior to isolation, when 1,2-dithiolanes are desired.

This method was eventually abandoned for the synthesis of 1,2-dithiolanes, but because of a longstanding interest also in biologically active 1,2,3-trithianes, ${ }^{6,7}$ the reaction mixture was examined prior to desulfurization. The interest in 1,2,3-trithianes originates from the fact that many naturally occurring 1,2-dithiolanes, e.g., 1,2-dithiolan-4-ol, ${ }^{8}$ asparagusic acid, ${ }^{8-12}$ nereis- toxin, ${ }^{13-18}$ and charatoxin ${ }^{17-20}$ have $1,2,3$-trithiane counterparts showing similar or enhanced biological activities.

\section{Results and discussion}

${ }^{1} \mathrm{H}$ NMR analyses of the product mixture from the reaction of compound 1 and sodium tetrasulfide revealed the presence of three closely related components. Comparison with authentic material allowed the assignment of a characteristic singlet at $\delta 3.72$ to diethyl 1,2-dithiolane-4,4dicarboxylate (2). ${ }^{1}$ Two additional singlets appearing at $\delta 3.60$ and 3.99 were assigned to diethyl 1,2,3-trithiane-5,5-dicarboxylate (3) and diethyl 1,2,3,4-tetrathiepane-6,6-dicarboxylate (4), respectively (Scheme 1). In this preparation, these three products were accompanied by a large number of by-products, making the purification of 2-4 quite troublesome. Chromato-

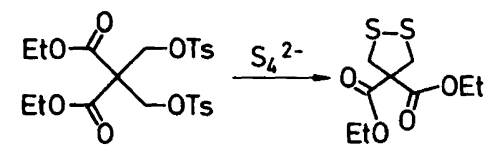

1<smiles>CCOC(=O)C12CCOC1(OCC)SSSC2</smiles>

3<smiles>CCOC(=O)C1(C(=O)OCC)CSSSS1</smiles>

4

Scheme 1 
graphic purification of the reaction mixture resulted in the isolation of an equimolar mixture of 2 and 3 and a fraction containing almost pure 4 as revealed by NMR spectroscopy and elemental analyses.

Owing to the problems encountered in product purification in the above-mentioned reaction, another preparative procedure was developed in order to gain easier access to 4 . We found that 2 reacts with an excess of elemental sulfur in hot $\mathrm{N}, \mathrm{N}$-dimethylformamide (DMF). The reaction produced a mixture of 2,3 and 4 in the ratio $5: 2: 2$, completely free of side-products. This mixture is separable by TLC. The rather low yield of 1,2,3,4-tetrathiepane $4(14 \%)$ is not a serious limitation since $\mathbf{2}$ and 3 are recoverable and may be recycled.

Presumably, the S-S dihedral angles in 4 are comparable to the normal value (i.e., ca. $90^{\circ}$ ) in contrast with those found in 1,2-dithiolanes. The photoelectron spectrum (PES) of $\mathbf{4}$ contains three separate signals in the low-energy area, two of which, around 10.2 and $11.4 \mathrm{eV}$, are assigned to the lone pairs on the carbonyl oxygen and the $\sigma$-lone pairs on sulfur, respectively. The $3 p$ lone pairs on sulfur give rise to a signal at $8.7 \mathrm{eV}$ without any recognizable splitting, indicating interactions of less than $0.3 \mathrm{eV}$. This is analogous to the findings for straight chain disulfides. ${ }^{21,22}$

Although 1,2,3,4-tetrahiepanes have not previously been described it is entirely possible that they have simply escaped previous notice. One brief report ${ }^{23}$ states that 5,5-disubstituted 1,2,3trithianes formed by the $\mathrm{S}_{4}{ }^{2-}$-ion reaction (cf. Ref. 2) may be separated from the simultaneously formed 1,2-dithiolane and thietane analogues by preparative TLC. However, no evidence other than $R_{\mathrm{f}}$ values is given. ${ }^{23}$ The alleged thietanes had the highest $R_{\mathrm{f}}$ values and were visualized on the plate with UV light $(254 \mathrm{~nm})$. We suspect that the latter compounds are in fact 1,2,3,4-tetrathiepanes since the sulfide chromophore does not absorb in this wavelength region.

The 1,2,3,4-tetrathiepane ring system is interesting from a biological point of view, not only because of the relationship with the bioactive 1,2-dithiolanes and 1,2,3-trithianes, but equally because this system may represent a physiologically acceptable form of reactive sulfur. Elemental sulfur is known to exhibit high bioactivity, for instance as an inhibitor of photosynthesis. ${ }^{18}$
These questions, as well as the generality of these preparative methods, are being investigated.

\section{Experimental}

The spectroscopic equipment is described in Ref. 1.

Diethyl 1,2,3,4-tetrathiepane-6,6-dicarboxylate (4): Method a. Diethyl 2,2-bis( $p$-tolylsulfonyloxymethyl)malonate (1) $(10 \mathrm{~g}, 18.9 \mathrm{mmol})$ was treated with $\mathrm{Na}_{2} \mathrm{~S}_{4}$ and the crude product mixture was isolated as described in Ref. 2. ${ }^{1} \mathrm{H}$ NMR (60 $\mathrm{MHz} ; \mathrm{CDCl}_{3}$ ) exhibited singlets at $\delta 3.60,3.72$ and 3.99. The signal at $\delta 3.72$ originates from $2 .{ }^{1}$ The mixture was purified twice by silica-gel chromatography using $\mathrm{CH}_{2} \mathrm{Cl}_{2}$-hexane $(2: 3)$ as the eluent for the first separation and toluene for the second. This procedure resulted in the isolation of nearly pure $4(0.34 \mathrm{~g}) 6 \%$ yield, based on 1 . Calc. for $\mathrm{C}_{9} \mathrm{H}_{14} \mathrm{O}_{4} \mathrm{~S}_{4}$ : C $34.38 ; \mathrm{H} 4.49 ; \mathrm{S} 40.78 \%$; Found: C 34.28; H 4.48; S 42.20\%. ${ }^{1} \mathrm{H}$ NMR (90 $\left.\mathrm{MHz} ; \mathrm{CDCl}_{3}\right): \delta 1.28\left(6 \mathrm{H}, \mathrm{t}, \mathrm{CH}_{3}\right), 3.93(4 \mathrm{H}, \mathrm{s}$, $\left.\mathrm{CH}_{2} \mathrm{~S}\right), 4.23$ (4 H, q, $\left.\mathrm{CH}_{2} \mathrm{O}\right) .{ }^{13} \mathrm{C}$ NMR $(22 \mathrm{MHz}$; $\left.\mathrm{CDCl}_{3}\right): \quad \delta 14.0 \quad\left(\mathrm{CH}_{3}\right), \quad 49.6 \quad\left(\mathrm{CH}_{2} \mathrm{~S}\right), \quad 62.4$ $\left(\mathrm{CH}_{2} \mathrm{O}\right), 67.1(\mathrm{C}), 168.7(\mathrm{CO})$. Another fraction gave a $1: 1$ mixture of 2 and 3 as a yellow oil. Yield $0.44 \mathrm{~g}, 9 \%$, based on 1. Anal. $\mathrm{C}_{9} \mathrm{H}_{14} \mathrm{O}_{4} \mathrm{~S}_{2.5}$ : $\mathrm{C}, \mathrm{H}, \mathrm{S} .{ }^{1} \mathrm{H}$ NMR $\left(60 \mathrm{MHz} ; \mathrm{CDCl}_{3}\right): \delta 1.30$ $\left(12 \mathrm{H}, \mathrm{t}, \mathrm{CH}_{3}\right), 3.63\left[4 \mathrm{H}, \mathrm{s}, \mathrm{CH}_{2} \mathrm{~S}(3)\right], 3.73$ [4 H, s, $\mathrm{CH}_{2} \mathrm{~S} \mathrm{(2)}$ ], $4.35\left(8 \mathrm{H}, \mathrm{dq}, \mathrm{CH}_{2} \mathrm{O}\right)$.

Method $b$. A solution of $2^{1}(1 \mathrm{~g}, 4 \mathrm{mmol})$ and sulfur $\left(3.5 \mathrm{~g}, 13.6 \mathrm{mmol}\right.$ of $\left.\mathrm{S}_{8}\right)$ in DMF $(20 \mathrm{ml})$ was kept at $120^{\circ} \mathrm{C}$ for $4 \mathrm{~h}$. The reaction mixture was allowed to cool to room temperature and excess sulfur was removed by filtration. Addition of water $(80 \mathrm{ml})$ followed by extraction with hexane $(6 \times 10 \mathrm{ml})$, washing of the combined hexane extract with water $(2 \times 10 \mathrm{ml})$, drying over $\mathrm{MgSO}_{4}$, and evaporation in vacuo left the crude product $(1.08 \mathrm{~g})$. Purification of this was achieved by applying the crude product dissolved in hexane $(7 \mathrm{ml})$ onto two silica gel plates (silica gel $60,100 \times 20 \times 0.25 \mathrm{~cm}$; PF 254 and $366 \mathrm{~nm}$ ). Elution 7 times with diethyl ether-hexane (1:20) produced a well separated upper band (4) followed by two poorly separated bands (upper 2 , lower 3). Elemental sulfur appeared near the front. The components were secured by thorough extraction of the isolated bands with diethyl ether, which was removed by evaporation to 


\section{TEUBER AND CHRISTOPHERSEN}

leave residues which were redissolved in a few $\mathrm{ml}$ of hexane. Filtration through silica gel $(5 \mathrm{~g})$ and elution with $\mathrm{CH}_{2} \mathrm{Cl}_{2}$ gave, after evaporation of the solvent, $4(195 \mathrm{mg})$ and 3 (100 mg containing approximately $10 \%$ of 2 ). After being recrystallised from pentane, 4 was obtained in $14 \%$ (176 mg). M.p. $34.5-36^{\circ} \mathrm{C}$. Anal. $\mathrm{C}_{9} \mathrm{H}_{14} \mathrm{O}_{4} \mathrm{~S}_{4}$ : C, H, S. MS: $m / z 314\left(\mathrm{M}^{+}\right)$. IR (KBr): $2960 \mathrm{w}, 2910 \mathrm{w}$, $1730 \mathrm{~s}, 1395 \mathrm{w}, 1365 \mathrm{w}, 1260 \mathrm{~m}, 1210 \mathrm{~m} \mathrm{~cm}^{-1}$. UV $(\mathrm{MeOH}): \lambda_{\max } 271 \mathrm{~nm}\left(\varepsilon 2.5 \times 10^{3}\right)$. NMR data as described above. PES, 8.7, 10.2, $11.4 \mathrm{eV}$.

Further purification of 3 was achieved by repetition of the chromatographic procedure $(100 \mathrm{mg}$ of the mixture dissolved in $3 \mathrm{ml}$ hexane) to yield $6 \%(68 \mathrm{mg})$ of pure 3 . ${ }^{1} \mathrm{H}$ NMR $(60 \mathrm{MHz}$; $\left.\mathrm{CDCl}_{3}\right): \delta 1.30\left(6 \mathrm{H}, \mathrm{t}, \mathrm{CH}_{3}\right), 3.56(4 \mathrm{H}, \mathrm{s}$, $\left.\mathrm{CH}_{2} \mathrm{~S}\right), 4.27\left(4 \mathrm{H}, \mathrm{q}, \mathrm{CH}_{2} \mathrm{O}\right)$. UV $(\mathrm{MeOH}): \lambda_{\max }$ $264 \mathrm{~nm}\left(\varepsilon 1.8 \times 10^{3}\right)$.

\section{References}

1. Teuber, L. and Christophersen, C. Acta Chem. Scand., Ser. B 42 (1988) 629.

2. Bergson, G. and Biezais, A. Ark. Kemi 22 (1964) 475 .

3. Backer, H. J. and Tasma, A. F. Recl. Trav. Chim. Pays-Bas 57 (1938) 1183.

4. Backer, H. J. and Evenhuis, N. Recl. Trav. Chim. Pays-Bas 56 (1937) 129.

5. Schotte, L. Ark. Kemi 9 (1956) 361.

6. Teuber, L. Sulfur Rep. In press.

7. Christophersen, C. and Anthoni, U. Sulfur Rep. 4 (1986) 365.

8. Kato, A. and Hashimoto, Y. In: Cavallini, D., Gaul, G. E. and Zappia, V., Eds., Natural Sulfur
Compounds Novel Biochemical and Structural Aspects, Plenum Press, New York 1980, p. 361.

9. Kitahara, Y., Yanagawa, H., Kato, T. and Takahashi, N. Plant Cell Physiol. 13 (1972) 923.

10. Yanagawa, H., Kato, T., Kitahara, Y., Takahashi, N. and Kato, Y. Tetrahedron Lett. (1972) 2549.

11. Yanagawa, H., Kato, T., Kitahara, Y. and Takahashi, N. Plant Cell Physiol. 14 (1973) 791.

12. Takasugi, M., Yachida, Y., Anetai, M., Masamune, T. and Kegasawa, K. Chem. Lett. 43 (1975).

13. Konishi, K. Agric. Biol. Chem. 32 (1968) 1199.

14. Injac, M. and Dulić, K. Proc. Br. Crop Prot. Conf. Pests Dis. 3 (1984) 1117.

15. Scott, G. C., Pickett, J. A., Smith, M.C., Woodcock, C. M., Harris, P. G. W., Hammon, R. P. and Koetecha, H. D. Proc. Br. Crop. Prot. Conf. Pests Dis. 1 (1984) 133.

16. Liu, A., Chen, X. and Shang, C. Kunchong Xuebao 28 (1985) [Chem. Abstr. 104 (1986) 145907b].

17. Anthoni, U., Christophersen, C., Madsen, J. Ø., Wium-Andersen, S. and Jacobsen, N. Phytochemistry 19 (1980) 1228.

18. Wium-Andersen, S., Anthoni, U., Christophersen, C. and Houen, G. Oikos 39 (1982) 187.

19. Jacobsen, N. and Pedersen, L.-E. K. Pestic. Sci. 14 (1983) 90.

20. Nielsen, L. E. and Pedersen, L.-E. K. Experientia 40 (1984) 186.

21. Bock, H., Stein, U. and Semkow, A. Chem. Ber. 113 (1980) 3208.

22. Rindorf, G., Jørgensen, F. S. and Snyder, J. P. J. Org. Chem. 45 (1980) 5343.

23. Goor, G. and Anteunis, M. Chromatographia 8 (1975) 41.

Received May 16, 1988. 